\title{
A FALÁCIA DA DESPEDIDA IMOTIVADA NO BRASIL
}

THE FALLACY OF IMPOSED DISMISSAL IN BRAZIL

Augusto Xavier de Carvalho*

\begin{abstract}
Resumo:
Levando-se em consideração que, historicamente, grandes perturbações sociais ocorreram em razão de problemas ligados ao trabalho, e que o desemprego é um dos principais problemas de uma sociedade capitalista, buscou-se elucidar um dos papéis fundamentais do Direito do Trabalho, qual seja, evitar o desemprego e a rotatividade desmedida da mão de obra. Neste sentido, desconstrói-se a teórica contemporânea que considera a despedida arbitrária como sinônimo de despedia imotivada, trazendo à tona as ilegalidades possibilitadas por este tipo de cessação do contrato de trabalho, buscando, ainda, demonstrar os vários motivos que justificam a imediata vedação à despedida arbitrária no Brasil, sob análises constitucionais, convencionais, principiológicas, internacionalistas, humanitárias e até mesmo, civilistas, para evitar, assim, o retrocesso social.
\end{abstract}

Palavras-chave: Despedida arbitrária. Tratados internacionais. Direitos humanos. Convenção n. 158 da OIT. Direitos Sociais.

\begin{abstract}
:
Taking into account that historically, great social disturbances occurred due to problems related to labor, and unemployment is one of the main problems of a capitalist society, it was tried to elucidate one of the fundamental roles of Labor Law, that is, avoiding unemployment and the excessive turnover of labor. In this sense, we deconstruct the contemporary theoretician who considers the arbitrary dismissal as synonymous with unmotivated dismissing, bringing to light the illegalities made possible by this type of termination of employment contract, also seeking to demonstrate the various reasons that justify the immediate prohibition of arbitrary dismissal in Brazil, under constitutional, conventional, principles, internationalist, humanitarian, and even civilian analyzes, to avoid, thus, social regression.
\end{abstract}

Keywords: Arbitrary dismissal. International treaties. Human rights. ILO Convention no. 158. Social Rights.

\section{Introdução}

A estrutura do sistema capitalista de produção faz com que a relação de trabalho não seja uma escolha, mas uma necessidade do ser humano, e o desemprego desmedido e despropositado seja considerado um mal a ser evitado e combatido, de forma a manter a ordem e paz sociais.

\footnotetext{
* Advogado, mestrando em Direito do Trabalho e da Previdência Social na Universidade de São Paulo, USP - e-mail: augustoxcarvalho@gmail.com.
} 
Neste contexto, o Direito do Trabalho, surgido com a finalidade de equilibrar forças neste sistema de produção, deve coibir as causas arbitrárias de cessação da relação de trabalho, dando forma ao princípio da continuidade da relação de trabalho, o qual já foi, inclusive, materializado pela Convenção n. 158 da Organização Internacional do Trabalho.

A hipótese que se apresenta, portanto, é a análise jurídica da vedação à despedida arbitrária no Brasil, sob um enfoque histórico das reais finalidades criadoras do Direito do Trabalho, sua relação com a OIT e os tratados internacionais sobre direitos humanos e, ainda, como o regime democrático brasileiro se legitimou pela adesão a estes tratados.

Como premissa maior, buscará demonstrar as relações reais das quais o Direito do Trabalho é expressão. Como direito social que é, este ramo do Direito está imerso no construído histórico dos direitos humanos e de seus tratados internacionais, os quais legitimaram jurídica e politicamente o sistema democrático brasileiro, reconhecendo constitucionalmente os direitos fundamentais como base principiológica plenamente acionável, pela nova hermenêutica jurídica.

Como premissa menor, abordará a importância da Organização Internacional do Trabalho e, particularmente, a Convenção n. 158 da OIT e seus aspectos formais, como a ratificação, a vigência e a denúncia, sendo esta última pormenorizada para verificação de sua validade.

No último capítulo, seguido da conclusão, chega-se aos resultados buscados pela análise histórico-dedutiva feita, pelas revisões bibliográficas necessárias e pela melhor abordagem jurisprudencial, para responder à questão: A vedação à despedida arbitrária é aplicável ao ordenamento jurídico interno brasileiro?

\section{Formação dos tratados internacionais sobre direitos humanos}

Aos acordos celebrados entre sujeitos de Direito Internacional Público, destinados a produzir efeitos jurídicos, se dá o nome de tratados, embora também sejam usadas outras denominações, dependendo da denotação que se queira conferir ao acordo celebrado, como: Convenção, Pacto, Protocolo, Carta, Convênio, Tratado ou Acordo Internacional. (REZEK, 2011, p. 38-40).

Entender a aplicabilidade destes tratados internacionais, mais especificamente daqueles que versem sobre direitos fundamentais, ao sistema jurídico interno brasileiro, implica discorrer sobre a afirmação histórica destes tratados, e sobre como o Brasil legitimou seu sistema democrático por meio da ratificação de tratados internacionais e pela reestruturação de sua soberania. 
O início do processo histórico de construção dos direitos fundamentais coincide com as revoluções científicas e tecnológicas, tendo na Revolução Francesa o engendramento dos direitos de liberdade e igualdade de todos perante a lei, consagrando, pela Declaração dos Direitos do Homem e do Cidadão, em 1789 (COMPARATO, 2010, p. 60-65), a primeira geração dos direitos fundamentais (BONAVIDES, 2009, p. 562-572).

Neste período, o liberalismo econômico buscou afastar o Estado absolutista monárquico das relações entre os particulares, sob o argumento jusnaturalista que entende não carecer de qualquer atuação estatal para realização dos direitos do homem, uma vez que estes lhe são inatos. Tal ideologia é característica marcante do Direito Civil, no qual o contrato é o signo da liberdade entre os particulares.

Com o advento das máquinas e a ascensão do capitalismo, possibilitando a Revolução Industrial, nasce a classe proletária que, destituída dos meios de produção e dependente da indústria, passa a vender sua força de trabalho por míseros salários, sendo submetida a condições desumanas para garantir sua sobrevivência, sem qualquer proteção por parte do Estado (COMPARATO, 2010, p. 65-67).

O Estado liberal acabou violando a dignidade humana por omissão, pois a classe operária não possuía de fato uma igualdade material em relação ao industrial, nem mesmo liberdade contratual para estipular suas condições de trabalho, gerando um grupo social assolado pela exploração de sua mão de obra, pela miséria, pela fome e pela marginalização. Os trabalhadores sucumbiram diante da necessidade lucrativa do industrial burguês e da omissão estatal possibilitada pela ideologia do Estado mínimo.

Esta perturbação trazida à sociedade em razão do desrespeito à dignidade humana, mais conhecida como questão social, afastou a ideia dos direitos inatos, ao trazer a necessidade de atuação do Estado por meio de uma releitura dos valores até então buscados, adequando-os à necessidade de produzir igualdade material, tal como prevista em lei, para a realização da liberdade tanto do industrial quanto do trabalhador (NASCIMENTO, 2009, p. 4).

Neste sentido, o Tratado de Versalhes, documento elaborado após o fim da Primeira Guerra Mundial, em 1919, é um marco do início do intervencionismo estatal. Este tratado reconhece que a paz universal só pode existir tendo por base a justiça social, expressando a necessidade de criação de uma organização internacional, a Organização Internacional do Trabalho - OIT, com a finalidade de zelar pela justiça social e pelo respeito à condição humana, principalmente no que diz respeito às condições de trabalho do homem.

Junto ao Tratado de Versalhes, o constitucionalismo social é outra importante marca do intervencionismo estatal, que buscou levar direitos sociais às constituições de diversos países. A primeira foi a Constituição do México em 1917, e logo em seguida, em 1919, a Constituição Alemã (COMPARATO, 2010, p. 66). 
Há que se ressaltar que esta é a gênese do surgimento do Direito do Trabalho, um direito social e, portanto, imerso na construção dos direitos fundamentais de segunda geração, o que faz com que ambos possuam finalidades comuns, como a realização da igualdade material e da justiça social para a efetiva proteção da humanidade.

Ainda que a assinatura de tratados internacionais e a constitucionalização dos direitos fundamentais tenham representado um grande avanço para a sociedade, não foram suficientes para evitar a barbárie ocorrida na Segunda Guerra Mundial, de 1939 a 1945, uma vez que não havia efetividade social destes direitos, ficando apenas no plano ideal, limitando-se ao argumento de existência programática destas normas.

As atrocidades cometidas durante a Segunda Guerra e o consequente sofrimento trazido à humanidade, levam à compreensão do valor supremo da dignidade humana, aprofundando e internacionalizando a afirmação histórica dos direitos fundamentais (BONAVIDES, 2009, p. 68). Assim, terminada a guerra, é reconhecida uma terceira geração de direitos fundamentais, esculpida no ideal de fraternidade: o direito ao desenvolvimento, à paz, ao meio ambiente, à comunicação e de propriedade sobre o patrimônio comum da humanidade (BONAVIDES, 2009, p. 569-570).

Em 1948, com a Declaração Universal dos Direitos do Homem - DUDH, há uma clara preocupação em imprimir positividade, concretude e eficácia à tríade geracional dos direitos fundamentais, regulamentados pelos tratados e inseridos nas constituições. Este novo entendimento não excluiu os direitos individuais, sociais ou difusos, mas os reuniu e os universalizou em uma única carta principiológica destinada a todo ser humano, juridificando, assim, a linguagem dos Direitos Humanos (BONAVIDES, 2009, p. 573-575).

A juridificação dos direitos humanos, em 1948, traz a ideia de um construído de direitos fundamentais cumulativos, fazendo com que o termo "geração" não mais traduza a real ideia dos direitos fundamentais, pois estes não são apenas sucessões cronológicas de direitos, mas sim dimensões necessariamente coexistentes para a construção da democracia.

Neste sentido, a Declaração Universal dos Direitos Humanos aponta o regime democrático como a única solução legítima de organização do Estado (COMPARATO, 2010, p. 246), deixando de intervir apenas na esfera normativa, para interferir profundamente nos regimes políticos autoritários existentes pelo mundo.

Assim, considera-se um erro continuar dividindo o papel do Estado, exigindose quanto aos direitos civis e políticos uma mera abstenção, por possuírem eficácia plena e, quanto aos direitos sociais, uma prestação positiva e programática, em razão de sua eficácia limitada (NASCIMENTO, 2011). O constitucionalismo contemporâneo entende que a atuação estatal é necessária e imprescindível para a realização de todo e qualquer direito fundamental. 
Em âmbito regional, nas Américas, tratados de paz também reconheceram a universalidade dos direitos humanos, entabulando uma solidariedade americana voltada à consolidação das liberdades individuais e da justiça social, como fundamento da democracia e do progresso (CARVALHO RAMOS, 2015, p. 247-249). A exemplo do Tratado de Bogotá (1948), o Pacto de São José da Costa Rica (1966) e a Organização dos Estados Americanos, que lançaram a base do Sistema Interamericano de Direitos Humanos - SIDH, causando grande impacto nas estruturas jurídicas e políticas brasileiras (GASPAR; MASTRODI, 2015, p. 117).

A submissão do Brasil ao Sistema Interamericano de Direitos Humanos ocorre durante a transição do sistema político autoritário para o democrático que, para afirmar-se como tal, necessitava tanto de reconhecimento internacional, possível somente pela submissão às pressões supraestatais exercidas pela linguagem dos direitos humanos, como de legitimação interna pelo diálogo do Estado com a sociedade (GASPAR; MASTRODI, 2015, p. 120).

Após mais de vinte anos de ditadura militar, o Brasil busca sua (re) democratização a exemplo dos "novos" regimes internacionais democráticos, que não mais admitem a utilização da violência para o exercício do Poder, sendo este somente legítimo pelo diálogo social entre os atores políticos (GASPAR; MASTRODI, 2015, p. 127).

A busca desta legitimação internacional e interna leva o Estado brasileiro a submeter-se ao Sistema Interamericano de Direitos Humanos, redesenhando os contornos de sua soberania, na qual o governo brasileiro cede parte de seu poder a entidades internacionais de defesa dos direitos humanos em um verdadeiro sistema de rendição de contas (accountability) (GASPAR; MASTRODI, 2015, p. 138), que passou a exercer forte pressão aos países violadores dos direitos humanos, utilizando-se, inclusive, de boicotes financeiros e políticos para tornar efetiva tal proteção.

Desta forma, a ratificação de tratados internacionais que versem sobre direitos humanos, nas palavras de Tércio Sampaio Ferraz Júnior:

[...] é um dado que implode o princípio da soberania, pois atinge o próprio direito processual que vê deslocada sua competência interna para uma situação de subordinação a decisões com base em outros centros irradiadores de normas, até sem a complacência da autoridade nacional. (FERRAZ JÚNIOR, 2013, p. 205).

Conclui-se que o sistema democrático brasileiro se legitimou jurídica e politicamente por uma forte releitura dos direitos fundamentais de primeira, segunda e terceira dimensões, que democratizaram e ramificaram o conceito de soberania estatal, principalmente pela ratificação de tratados internacionais. 
2. Incorporação pela constituição brasileira e a eficácia dos tratados internacionais sobre direitos humanos

A Constituição Federal de 1988, em seus arts. 84, VIII, e 49, I, prevê a colaboração entre Executivo e Legislativo para a conclusão de tratados internacionais. Portanto, depois de negociados e assinados pelo órgão do Poder Executivo, entende-se que os tratados internacionais tradicionais possuem um aceite precário e provisório, não produzindo efeitos jurídicos vinculantes ao país signatário (PIOVESAN, 2010, p. 47).

Em seguida, o segundo passo para aprovação de um tratado internacional é ser referendado pelo Poder Legislativo, no caso brasileiro o Congresso Nacional (PIOVESAN, 2010, p. 49).

Aprovado pelo Poder Legislativo, o tratado deve ser ratificado pelo Poder Executivo, na pessoa do Presidente da República, para que possa ter obrigatoriedade no âmbito internacional e interno (PIOVESAN, 2010, p. 48).

Por fim, o instrumento de ratificação do tratado internacional deve ser depositado em um órgão que assuma a custódia do instrumento, a exemplo da Organização das Nações Unidas, Organização dos Estados Americanos (PIOVESAN, 2010, p. 49) ou mesmo na Repartição Internacional do Trabalho da OIT.

Assumidas estas formalidades, passam os tratados internacionais a serem jurídica e politicamente obrigatórios em âmbito internacional, responsabilizando os países signatários por eventual descumprimento das obrigações firmadas (PIOVESAN, 2010, p. $50)$.

Os tratados tradicionais vinculam os Estados no exato momento de sua ratificação. Contudo, devem ser submetidos ao Poder Legislativo para que tenham eficácia interna e gerem direitos subjetivos entre os particulares (PIOVESAN, 2010, p. 86).

Quanto à eficácia interna dos tratados internacionais sobre direitos humanos, cabe entender como a Constituição brasileira de 1988, de forma inédita, os recepcionou no $\S 2^{\circ}$ de seu art. $5^{\circ}$ :

Os direitos e garantias expressos nesta Constituição não excluem outros decorrentes do regime e dos princípios por ela adotados, ou dos tratados internacionais em que a República Federativa do Brasil seja parte.

Assim, considerando que o art. $5^{\circ}$ da Constituição Federal está inserido no título dos Direitos Fundamentais, conclui-se que os tratados internacionais que versem sobre direitos humanos integram o rol dos direitos constitucionalmente assegurados, enquanto os tratados internacionais tradicionais possuem força hierárquica infraconstitucional (PIOVESAN, 2010, p. 59). 
Flávia Piovesan sustenta que os tratados tradicionais têm hierarquia infraconstitucional, mas supralegal. Chega a este entendimento pela interpretação do art. 102, III, b, da Constituição Federal de 1988, bem como do princípio da boa-fé, orientado pelo art. 27 da Convenção de Viena, o qual estabelece que não cabe invocar disposições de seu Direito interno como justificativa para o não cumprimento de tratado (PIOVESAN, 2010, p. 60).

Reconhecida a natureza constitucional dos tratados internacionais que versem sobre direitos humanos, estes, assim como os demais direitos individuais consagrados pela Constituição, são considerados cláusulas pétreas conforme inciso IV, § $4^{\circ}$ do art. 60 da Constituição Federal (PIOVESAN, 2010, p. 84).

Ao analisar os direitos fundamentais como cláusulas pétreas, George Marmelstein faz a seguinte analogia:

\begin{abstract}
Eles seriam como aqueles frascos de remédio que são colocados nas prateleiras mais altas para ficar longe do alcance das crianças. A analogia só não é tão perfeita porque aqueles que estão em situação de poder não são crianças ingênuas, mas homens crescidos e perspicazes, lutando com unhas e dentes por seus interesses nem sempre nobres. (MARMELSTEIN, 2014, p. 285).
\end{abstract}

Quanto à eficácia das normas que traçam os direitos e garantias fundamentais, a Constituição de 1988 consagra o princípio da aplicabilidade imediata dessas normas, em seu art. $5^{\circ}, \S 1^{\circ}$ (PIOVESAN, 2010, p. 35). Em outras palavras, enquanto os tratados internacionais tradicionais dependem de legislação intermediadora para exigibilidade interna destes, os que versam sobre direitos humanos possuem aplicabilidade e exigibilidade internas imediatas, nos termos do $\S 1^{\circ}$ do art. $5^{\circ}$ da Constituição Federal.

Para Canotilho (1993, p. 578), esta aplicação imediata não significa apenas que estes direitos e garantias se aplicam sem a interferência legislativa, mas também que estes valem contra a lei. Assim, a partir da ratificação do tratado internacional sobre direitos humanos, qualquer norma interna preexistente que seja com ele incompatível perderá imediatamente a vigência (PIOVESAN, 2010, p. 86).

Qualquer conflito que porventura venha a existir entre o Direito Internacional dos Direitos Humanos e o Direito interno seguirá o critério da prevalência mais favorável à pessoa humana (PIOVESAN, 2010, p. 105).

Não sem controvérsias, houve o entendimento de como os tratados internacionais foram recepcionados pela Constituição. Em resposta à polêmica doutrinária e jurisprudencial quanto à hierarquia, em relação à Constituição Federal, dos tratados internacionais de proteção aos direitos humanos, a Emenda Constitucional n. 45/2004 trouxe o $\S 3^{\circ}$ ao art. $5^{\circ}$, senão vejamos: 
Os tratados e convenções internacionais sobre direitos humanos que forem aprovados, em cada Casa do Congresso Nacional, em dois turnos, por três quintos dos votos dos respectivos membros, serão equivalentes às emendas constitucionais.

Contudo, a introdução deste novo entendimento não significa dizer que os tratados internacionais sobre direitos humanos já ratificados, por não possuírem o novo “quórum" exigido em referido parágrafo, passariam a ser recepcionados como normas infraconstitucionais. Todos os tratados sobre direitos fundamentais, independentemente de seu "quórum" de aprovação, são materialmente constitucionais, haja vista a predominância material que deve condicionar a forma no plano jurídico-normativo, e não o oposto (PIOVESAN, 2010, p. 72).

\section{Força normativa dos princípios}

O constitucionalismo social, que marcou a transição do Estado Liberal para o Estado Social, ampliou os horizontes das constituições, que até então disciplinavam somente o poder estatal e os direitos individuais (civis e políticos), passando a regular as esferas do poder do Estado, a sociedade e o indivíduo (BONAVIDES, 2009, p. 229).

Este novo modelo político estruturou as constituições num caráter principiológico de disposições programáticas, que estabeleciam regras relativas a futuros comportamentos estatais. Contudo, a programaticidade das normas constitucionais impede sua real eficácia, pois os juristas, abraçados à tese antinormativa da Constituição, justificam a inobservância de suas regras e princípios alegando seu caráter meramente norteador da sociedade (BONAVIDES, 2009, p. 237).

Com a evolução das teorias jurídicas pós-positivistas, os princípios passam a ser tratados como direito, e as constituições, nas palavras de Paulo Bonavides, "acentuam a hegemonia axiológica dos princípios, convertidos em pedestal normativo sobre o qual assenta todo o edifício jurídico dos novos sistemas constitucionais". (BONAVIDES, 2009, p. 264).

Mais detalhadamente, Bonavides perfaz o caminho de evolução da teoria da força normativa dos princípios:

Em resumo, a teoria dos princípios chega à presente fase do pós-positivismo com os seguintes resultados já consolidados: a passagem dos princípios da especulação metafísica e abstrata para o campo concreto e positivo do Direito, com baixíssimo teor de densidade normativa; a transição crucial da ordem jusprivatista (sua antiga inserção nos Códigos) para a órbita juspublicística (seu ingresso nas Constituições); a suspensão da distinção clássica entre 
princípios e normas; o deslocamento dos princípios da esfera da jusfilosofia para o domínio da ciência jurídica; a proclamação de sua normatividade; a perda de seu caráter de normas programáticas; o reconhecimento definitivo de sua positividade e concretude por obra sobretudo das Constituições; a distinção entre regras e princípios, como espécies diversificadas do gênero norma, e, finalmente, por expressão máxima de todo este desdobramento doutrinário, o mais significativo de seus efeitos; a total hegemonia e preeminência dos princípios. (BONAVIDES, 2009, p. 18).

Alçados, os princípios constitucionais, a normas plenamente acionáveis, independentemente de regulamentação legislativa, estes passam a ser base do Estado Democrático de Direito e da Constituição da República Federativa do Brasil, definidos entre os Princípios Fundamentais, o da dignidade da pessoa humana; os valores sociais do trabalho e da livre iniciativa (art. $1^{\circ}$, III e IV); a construção de uma sociedade livre, justa e solidária; a garantia do desenvolvimento econômico; a erradicação da pobreza e da marginalização e a redução das desigualdades sociais e regionais; a promover do bem de todos, sem preconceitos de origem, raça, sexo, cor, idade e quaisquer outras formas de discriminação (art. $3^{\circ}$, I, II, III e IV); a independência nacional e a prevalência dos direitos humanos (art. $4^{\circ}$, I e II). (TRIBUNAL REGIONAL DO TRABALHO DA $15^{\mathrm{a}}$ REGIÃO, 2009).

E, por fim, seguindo a linha principiológica do referido art. $4^{\mathrm{o}}$, na Conferência Mundial de Direitos Humanos, realizada em Viena em 1993, é reconhecido o importante princípio da complementaridade solidária dos direitos humanos de qualquer espécie, o qual ensina que:

Todos os direitos humanos são universais, indivisíveis, interdependentes e inter-relacionados. A comunidade internacional deve tratar os direitos humanos globalmente, de modo justo e equitativo, com o mesmo fundamento e a mesma ênfase. Levando em conta a importância das particularidades nacionais e regionais, bem como os diferentes elementos de base históricos, culturais e religiosos, é dever dos Estados, independentemente de seus sistemas políticos, econômicos e culturais, promover e proteger todos os direitos humanos e as liberdades fundamentais. (COMPARATO, 2010, p. 80).

Esse princípio tem como postulado ontológico a existência da mesma essência em todo ser humano, respeitadas suas inúmeras diferenças, reconhecendo a universalidade e a abrangência dos direitos humanos. 
4. Convenção n. 158 e o conceito de despedida arbitrária

Reconhecida a OIT como a "consciência social da humanidade" (ORGANIZAÇÃO INTERNACIONAL DO TRABALHO, 2012), apta a promover a paz e a justiça social, pela proteção do trabalho do homem e, consequentemente, dos direitos humanos, passa a ser reconhecida também como grande realizadora do princípio fundamental que orienta o Direito do Trabalho, o princípio da proteção.

Este princípio traduz o fim último do Direito do Trabalho de compensar a desvantagem econômica do trabalhador por meio de proteções jurídicas, sendo os demais princípios realizadores daquele e, nas palavras do autor argentino Eduardo Alvarez (1985, p. 471 apud PLÁ RODRIGUES, 2000, p. 242):

Se partirmos da realidade de admitir a existência de um direito na medida de sua efetividade, verificaremos que a tutela da permanência no emprego aparece como uma das máximas realizações do princípio de proteção, porque deu origem à autotutela dos trabalhadores, permitiu a acabada vigência de seus direitos subjetivos e atuou como real compensação de desigualdade.

Entende-se, portanto, que nenhum direito trabalhista pode ser plenamente respeitado e/ou exigido diante da possibilidade do término unilateral e arbitrário da relação de trabalho.

Na linha desta grande máxima realizadora da finalidade do Direito do Trabalho, a OIT aprovou na $68^{\mathrm{a}}$ reunião da Conferência Internacional do Trabalho (Genebra - 1982), a Convenção n. 158, para tratar do término da relação de trabalho por iniciativa do empregador, que entrou em vigor no plano internacional em 23 de novembro de 1985 (SUSSEKIND, 1998).

Referida convenção elucida os únicos motivos válidos a ensejar o término da relação de trabalho, em seu art. $4^{\circ}$, senão vejamos:

Não se dará término à relação de trabalho de um trabalhador a menos que exista para isso uma causa justificada relacionada com sua capacidade ou seu comportamento ou baseada nas necessidades de funcionamento da empresa, estabelecimento ou serviço.

Desta leitura depreende-se que qualquer ruptura da relação de trabalho que se dê por motivo que não seja relacionado à capacidade ou ao comportamento do trabalhador, ou ainda que não se baseie nas necessidades de funcionamento da empresa, estabelecimento ou serviço, será considerada arbitrária.

$\mathrm{O}$ art. $5^{\circ}$ da Convenção enumera um rol exemplificativo dos motivos que não constituem causa justificada para o término da relação de trabalho; ou seja, motivos 
arbitrários. O primeiro motivo é a filiação a sindicato ou a participação em atividades sindicais fora das horas de trabalho ou, com o consentimento do empregador, durante as horas de trabalho. O segundo é a candidatura a representante dos trabalhadores ou atuar ou ter atuado nessa qualidade. O terceiro é a apresentação de queixa ou a participação de procedimento estabelecido contra um empregador por supostas violações de leis ou regulamentos, ou recorrer perante as autoridades administrativas competentes. O quarto é a raça, a cor, o sexo, o estado civil, as responsabilidades familiares, a gravidez, a religião, as opiniões políticas, ascendência nacional ou a origem social. O quinto é a ausência do trabalho durante a licença-maternidade.

E, por fim, o art. $6^{\circ}$ traz que a ausência temporal do trabalho por motivo de doença ou lesão não deverá constituir causa justificada de término da relação de trabalho.

Em atenção ao princípio do contraditório e da ampla defesa, a Convenção n. 158 dá a oportunidade de recurso ao término da relação de trabalho, ao trabalhador que considerar injustificado tal rompimento, sendo aplicado ao empregador o ônus da prova da existência de causa justificadora para o término, assim como definido no art. $4^{\circ}$.

No Brasil, os termos da Convenção n. 158 foram aprovados pelo Congresso Nacional, por meio do Decreto Legislativo n. 68, de 16 de setembro 1992; a carta de ratificação foi depositada na Repartição Internacional do Trabalho (da OIT), em 5 de janeiro de 1995; e tornados públicos pelo Decreto de promulgação n. 1.855, de 10 de abril de 1996 (SOUTO MAIOR, 2004).

Ocorre que o Poder Executivo denunciou a Convenção n. 158 da OIT, mediante o Decreto n. 2.100, de 20 de dezembro de 1996, publicado no dia 23 deste mesmo mês e ano, tendo enviado carta à OIT, em 20 de novembro de 1996, explicitando que tal Convenção deixaria de ter vigência no ordenamento jurídico brasileiro a partir de 20 de novembro de 1997 (SOUTO MAIOR, 2004).

\section{Inconstitucionalidade da denúncia}

$\mathrm{Na}$ ação direta de inconstitucionalidade - ADI n. 1.625-3, proposta pela Confederação Nacional dos Trabalhadores na Agricultura - CONTAG e pela Central Única dos Trabalhadores - CUT, contra o Decreto n. 2.100, de 20 de dezembro de 1996, que tornou pública a denúncia da Convenção n. 158 da OIT, Arnaldo Sussekind emitiu parecer jurídico (SUSSEKIND, 1997), ao ser consultado pela CUT, entendendo pela invalidade formal da denúncia da Convenção n. 158, com fundamento em seu art. 17, § $1^{\circ}$, que dispõe:

Todo membro que tiver ratificado a presente Convenção poderá denunciá-la no fim de um período de 10 (dez) anos, a partir da data da entrada em vigor inicial, mediante um ato comunicado, para ser registrado, ao Diretor-Geral da 
Repartição Internacional do Trabalho. A denúncia tornarse-á efetiva somente 1 (um) ano após a data de seu registro.

Quando à faculdade de exercitar a denúncia, Sussekind entende que esta é atribuída ao Membro da Organização, e não ao governo.

Ressalta que os arts. $1^{\circ}$ e $3^{\circ}$ da Constituição da OIT deixam claro o extremo cuidado com a nomenclatura jurídica usada para distinguir as expressões Estado e Governo. ${ }^{1}$ Concluindo que, para a OIT, a expressão Membro corresponde a Estado, no sentido de Nação, englobando também os trabalhadores e empregadores que, em conjunto com os governos, formam a entidade internacional, apta a exercitar a faculdade de denúncia.

Neste mesmo sentido, a Convenção n. 144 de 1976 (SUSSEKIND, 1998), ratificada e vigente no Brasil, que dispõe sobre "Consultas tripartites para promover a aplicação das normas internacionais do trabalho", traz em seu art. $2^{\circ}$ :

Todo Membro da Organização Internacional do Trabalho que ratifique a presente Convenção compromete-se a pôr em prática procedimentos que assegurem consultas efetivas, entre os representantes do Governo, dos empregadores e dos trabalhadores, sobre os assuntos relacionados com as atividades da Organização Internacional do Trabalho a que se refere o artigo 5, parágrafo 1 , adiante.

Referido art. 5, estabelece:

1. O objetivo dos procedimentos previstos na presente Convenção será a de celebrar consultas sobre:

(...) e) as propostas de denúncia de convenções ratificadas.

Acrescenta que o art. $3^{\circ}$, da Convenção n. 144, estabelece que:

1. Os representantes dos empregadores e dos trabalhadores, para efeitos dos procedimentos previstos na presente Convenção, serão eleitos livremente por suas organizações representativas, sempre que tais organizações existam.

\footnotetext{
Art. $1^{\circ}$. Serão Membros da Organização Internacional do Trabalho os Estados que eram Membros da Organização em $1^{\circ}$ de novembro de 1945 e qualquer outro Estado que adquira a qualidade de Membros de conformidade com as disposições dos parágrafos 3 e 4 deste artigo; Art. $3^{\circ}$. A Conferência Geral dos representantes dos Membros celebrará reunião uma vez que seja necessário e, pelo menos, uma vez ao ano; será composta de quatro representantes de cada um dos Membros, dois dos quais serão delegados do governo e os outros dois representantes, respectivamente, os empregados e os trabalhadores de cada um dos Membros. cf., (ORGANIZAÇÃO INTERNACIONAL DO TRABALHO, 1946).
} 
2. Os empregadores e os trabalhadores estarão representados em pé de igualdade em qualquer organismo mediante o qual sejam levadas a cabo as consultas.

Desta feita, a denúncia à Convenção n. 158 é, sob a análise formal, inaceitável, pois não levou a cabo a exigência das “consultas efetivas" dos Estados Membro, de maneira a dar voz às vontades do governo, dos empregadores e dos trabalhadores.

Quanto ao prazo para a denúncia previsto no $\S 1^{\circ}$ do art. 17 da Convenção n. 158, já transcrito, Sussekind considera que o decênio tem início da ratificação de cada país. Contudo, o entendimento da OIT considera o início da vigência da convenção no plano internacional.

Para defender seu entendimento, Sussekind analisa o disposto no $\S 2^{\circ}$ deste mesmo artigo, dizendo: "ficará obrigado, durante um novo período de dez anos e, sucessivamente, poderá denunciar esta convenção à expiração de cada período de dez anos, nas condições previstas neste artigo".

Considera, portanto, que se o parágrafo faz referência a "um novo período de dez anos" para a vigência da ratificação nacional, é porque antes fluiu outro decênio, o internacional. Diz, ainda, não ser logicamente pensável que um país possa denunciar uma convenção que ratificou há dias, pelo fato de estar vigente no plano internacional há dez anos. Corroborando este entendimento, traz a declaração de João Carlos Alexim, o então Diretor da OIT no Brasil, que disse em entrevista para o Jornal Trabalhista n. 636, de 2 de dezembro de 1996, que o "procedimento adotado até hoje não é o mais justo, o mais lógico".

Contudo, levando em consideração o entendimento até então adotado pela OIT, os doze meses em que se poderia ter denunciado a Convenção n. 158 fluíram entre 23 de novembro de 1995 a 22 de novembro de 1996, haja vista o início da vigência internacional ter ocorrido em 23 de novembro de 1985, tornando, assim, tempestiva a denúncia brasileira oficialmente comunicada ao Diretor-Geral da RIT em 20 de novembro de 1996.

Importante pontuar que este estudo não compartilha do entendimento adotado pela OIT, quanto ao início da contagem do decênio; entendendo, conforme fundamentação já explicitada, que este tem início na data de ratificação de cada país, fazendo da denúncia intempestiva e, portanto, inválida.

Após os votos dos ministros Maurício Correa, Carlos Britto e Nelson Jobim, o então ministro Joaquim Barbosa ${ }^{2}$ pediu vista dos autos para propor suas considerações.

O ministro Maurício Correa não conheceu da ação em relação à CUT e, no mérito, considerou imprescindível a participação do parlamento na denúncia de tratados. O ministro Carlos Britto acompanhou o voto do relator. Já o ministro Nelson Jobin entendeu pela improcedência da ação. cf., (SUPREMO TRIBUNAL 
Primeiramente, relembra que outra ADI, de n. 1.480, discutiu a constitucionalidade do Decreto que incorporou a Convenção n. 158 ao direito brasileiro e, antes que fosse analisado seu mérito, o governo brasileiro denunciou referida convenção, dando publicidade à denúncia pelo Decreto n. 2.100/1996. Após a denúncia, o Ministro Celso de Mello julgou extinta a ADI n. 1.480, baseando-se na perda do objeto da ação. Nesse contexto se insere o imbróglio da ADI n. 1.625-3, que discute a validade da denúncia.

Em seu voto, Joaquim Barbosa, embora reconheça que a Constituição Federal de 1988 é omissa quanto ao tema da denúncia de tratados internacionais, analisa a competência atribuída ao Congresso Nacional e ao Presidente da República em respeito aos tratados internacionais, para encontrar a solução mais adequada ao caso.

De acordo com o art. 49, I, da CF, compete exclusivamente ao Congresso Nacional, "resolver definitivamente sobre tratados, acordos ou atos internacionais que acarretam encargos ou compromissos gravosos ao patrimônio nacional".

Ao Presidente da República, o art. 84, VIII, atribui a competência de "celebrar tratados, convenções e atos internacionais, sujeitos a referendo do Congresso Nacional".

Considerando não ser explícita, a Constituição, quanto à necessidade de participação do Congresso Nacional na denúncia de tratados, Joaquim Barbosa aborda historicamente tais dispositivos constitucionais, relembrando que a Constituição brasileira de 1891, sob a influência da Constituição norte-americana, aderiu ao "treatymaking power" entre o Presidente e o Congresso, incluídos a Câmara dos Deputados e o Senado Federal, substituindo o "aconselhamento e consentimento" adotados pelos norteamericanos, pela expressão "resolver definitivamente".

O “treaty-making power" norte-americano está tão presente em nosso ordenamento jurídico, que a aprovação da própria Convenção n. 158 da OIT foi realizada pelo Congresso Nacional, com a edição do Decreto Legislativo n. 68/1992, nos seguintes termos:

Art. $1^{\circ}$. É aprovado o texto da Convenção n. 158, da Organização Internacional do Trabalho (OIT), sobre o término da Relação do Trabalho por iniciativa do empregador, adotada em Genebra, em 1982.

Parágrafo único. São sujeitos à aprovação do Congresso Nacional quaisquer atos que possam resultar em revisão da referida convenção, bem como aqueles que se destinem a estabelecer ajustes complementares.

FEDERAL s.d.). 
Art. $2^{\circ}$. Este Decreto Legislativo entra em vigor na data de sua publicação.

A previsão do parágrafo único, do artigo transcrito, deixa claro que a interação entre Presidente e Parlamento não deve existir apenas na elaboração e ratificação dos tratados, mas também no chamado "treaty-terminating power", ou seja, no poder de extinguir os tratados.

Para Barbosa, a Constituição fortaleceu enormemente o papel do Poder Legislativo no que se refere, por exemplo, à fiscalização da atuação de órgãos estatais e à investigação de fatos. Defende que a existência de um regime que conta com um parlamento forte, deve dar voz às minorias e milita contra as presunções de papel reduzido do Poder Legislativo na processualística dos tratados internacionais.

Cita diversas constituições estrangeiras que outorgam ao Legislativo papel ativo em relação à denúncia de tratados, como na Dinamarca, Holanda, Espanha, Rússia, Azerbaijão, Estônia, Paraguai, Peru, Chile, lembrando que até mesmo nos Estados Unidos têm sido abertas possibilidades de maior participação do legislativo no "treaty-terminating power".

Joaquim Barbosa ainda traz em seu voto o raciocínio de Pontes de Miranda:

(...) aprovar tratado ou convenção, permitindo que o Poder Executivo o denuncie, sem consulta, nem aprovação, é subversivo dos princípios constitucionais. O Presidente da República pode apresentar projeto de denúncia, ou denunciar o tratado ou convenção, ad referendum do Poder Legislativo. Se o poder Judiciário julga inconstitucional o tratado ou convenção, deve o Senado Federal suspender-lhe a execução, e o Presidente da República imediatamente, não ao julgamento, mas à suspensão, denunciá-lo. Se o tratado ou convenção só beneficia o Brasil, a denúncia precisa, a fortiori, ser aprovada pelo Poder Legislativo. Diga-se o mesmo m relação aos tratados de paz, pois a Constituição exige a própria autorização prévia para o Presidente da República negociar a paz. (MIRANDA, 1960, p. 476-477 apud SUPREMO TRIBUNAL FEDERAL s.d.).

E, nas palavras do próprio relator Joaquim Barbosa, a denúncia unilateral de tratados pelo Poder Executivo:

produz uma anomalia jurídica não encontrável em nenhuma parte da Constituição, mas apenas em constituições autoritárias que permitiam a existência, por exemplo, do decreto-lei, um ato normativo que já indica em seu próprio nome uma contradição em termo.

Por fim, Fábio Konder Comparato também milita no mesmo sentido, afirmando que: 
o poder de denunciar uma convenção internacional só faz sentido quando esta cuida de direitos disponíveis. Em matéria de tratados internacionais de direitos humanos, não há nenhuma possibilidade jurídica de denúncia, ou de cessação convencional da vigência, porque se está diante de direitos indisponíveis e, correlatamente, de deveres insuprimíveis. (COMPARATO, 2010, p. 79-80).

Portanto, não bastassem todos os argumentos apresentados, o fato de se tratar a Convenção n. 158 da OIT de um tratado internacional de direitos humanos, mais especificamente um tratado sobre direitos sociais, vai ao encontro da previsão constitucional do art. $4^{\circ}$ da Constituição Federal, que estabelece a prevalência dos direitos humanos como princípio norteador das relações exteriores do Brasil.

\section{Razões de vedação à despedida arbitrária no Brasil}

O fato de a democracia brasileira ter se legitimado jurídica e politicamente pela releitura da tríade dos direitos humanos fundamentais, com a consequente reestruturação de sua soberania, pela submissão a órgãos internacionais, como a OIT (reconhecida como consciência social da humanidade), faz com que as convenções e tratados por ela entabulados sejam não só internacionalmente reconhecidos, mas constitucionalmente aceitos e aplicáveis.

Constitucionalmente reconhecida, a Convenção n. 158 da OIT não é passível de denúncia por estar entre os direitos fundamentais conquistados pela humanidade e, ainda que pudesse ser denunciada, é inválida a maneira como esta se deu no Brasil, seja pela intempestividade, pela ausência de consultas efetivas às categorias representativas dos trabalhadores e empregadores, ou pela não participação do Congresso Nacional no processo de denúncia.

A base principiológica que fundamenta a Convenção n. 158 e a nova hermenêutica constitucional, fazem com que esta não seja apenas plenamente aplicável sem interferência legislativa, mas também que se aplique contra qualquer norma preexistente que seja com ela incompatível.

Mas, independentemente da aplicação da Convenção n. 158 da OIT, não se pode aceitar que a dispensa de empregados ocorra com abuso de direitos, claramente identificado quando o trabalhador encontra-se doente, doenças estas muitas vezes adquiridas pelas condições precárias de trabalho; ou mesmo para a contratação de outro trabalhador mais novo que invariavelmente aceitará trabalhar mais por um salário menor; ou para economizar, com a substituição de empregados por trabalhadores terceirizados, dentre outras formas de contratos precários. 
O constante medo do desemprego e, com ele, a perda de todas as garantias trabalhistas conquistadas com tanto sacrifício, inclusive a ameaça à subsistência do trabalhador e de sua família, faz com que o exercício do direito potestativo do empregador, em demitir seus empregados, encontre entraves não só na noção do abuso de direito, mas também no princípio da boa-fé, no qual as partes da relação jurídica contratual não devem quebrar a confiança natural e recíproca.

Pensar no conceito de abuso de direito e na quebra da boa-fé contratual para análise das razões à vedação da despedida arbitrária, não significa aceitar a teoria contratualista do direito do trabalho. Admitir tal teoria seria negar a afirmação histórica deste direito social, imerso na construção dos direitos humanos. Apenas desenvolve-se tal argumento para demonstrar que na mais liberal das interpretações, deve-se coibir a prática da despedida arbitrária, nas relações de trabalho.

Nesta teoria, embora haja liberdade das partes em contratar, o contrato deve ser pautado em sua função social, nos termos do art. 421 do Código Civil, sendo que a boa-fé deve estar presente em sua formação, execução e extinção, o que se depreende da análise conjunta ao art. 472 do mesmo Código.

Assim, qualquer motivo de dispensa, pelo empregador, que não esteja relacionado à capacidade ou ao comportamento do trabalhador, ou ainda que não se baseie nas necessidades de funcionamento da empresa, estabelecimento ou serviço, fere a boafé contratual, devendo ser considerado arbitrário, e, portanto, ilícito para fins do art. 187 do Código Civil, o qual prevê que "o titular de um direito que, ao exercê-lo, excede manifestamente os limites impostos pelo seu fim econômico ou social, pela boa-fé ou pelos bons costumes" (BRASIL, 2002), comete ato ilícito.

Os reflexos da não vedação à despedida arbitrária são tão preocupantes que interferem, inclusive, no acesso à justiça, por estar o empregado "impedido" de pleitear judicialmente, no curso de seu contrato de trabalho, direitos trabalhistas não respeitados por seu empregador, pois a represália seria inevitável e legitimada pela falácia da dispensa "imotivada". Sobre esta fragilidade do trabalhador traz Souto Maior, em seu artigo "A Fúria":

Essa distorção repercute até nos pedidos. Ninguém vai à Justiça para exigir, por exemplo, o cumprimento de normas de higiene e segurança do trabalho. Ou pedindo que o juiz fixe a data de suas férias não gozadas no prazo legal. Do mesmo modo, nenhum empregado transferido ilicitamente requer a volta ao lugar de origem, como a lei garante, até em caráter liminar. Na prática, todo o contrato pode ser alterado, mesmo de forma ilegal, sem que o patrão seja compelido a recolocá-lo nos eixos. O que se pede, sempre, são reparações financeiras. E o que é pior: mesmo elas, em geral, não conseguem reparar tudo: sobre os direitos 
teóricos desaba o peso da prescrição, que se faz acompanhar, não raras vezes, com a ineficiência da execução. E assim se completa o trabalho de desconstrução da norma - que se iniciara no chão da fábrica - pelas mãos do próprio empregador. (VIANA, 2001, p. 20).

Quer seja feita uma análise principiológica, convencional, internacionalista, humanitária ou, na pior das hipóteses, civilista, o ordenamento jurídico brasileiro, calcado na nova hermenêutica, não recepciona o instituto da despedida arbitrária, devendo este ser expurgado das relações laborais.

\section{Aplicação de convenção internacional não ratificada}

Partindo do errôneo pressuposto de validade da denúncia da Convenção n. 158 da OIT, resta analisar a proteção contra a despedida arbitrária sob a ótica constitucional do art. $7^{\circ}, \mathrm{I}$ :

Art. $7^{\circ}$. São direitos dos trabalhadores urbanos e rurais, além de outros que visem à melhoria de sua condição social:

I - relação de emprego protegida contra despedida arbitrária ou sem justa causa, nos termos de lei complementar, que preverá indenização compensatória, dentre outros direitos.

Mais adiante, o art. 10, inciso I, do Ato das Disposições Constitucionais Transitórias aumentou a indenização de 10 para $40 \%$, sobre o saldo do FGTS, nos seguintes termos:

Art. 10. Até que seja promulgada a lei complementar a que se refere o art. $7^{\circ}$, I, da Constituição:

I - fica limitada a proteção nele referida ao aumento, para quatro vezes, da porcentagem prevista no art. $6^{\circ}$, "caput" $e$ $\S 1^{\circ}$, da Lei $n$. 5.107, de 13 de setembro de 1966;

II - fica vedada a dispensa arbitrária ou sem justa causa:

a) do empregado eleito para cargo de direção de comissões internas de prevenção de acidentes, desde o registro de sua candidatura até um ano após o final de seu mandato;

b) da empregada gestante, desde a confirmação da gravidez até cinco meses após o parto. (Grifo nosso).

Até que seja promulgada referida lei complementar, percebe-se que o inciso "I" remete à lei que cria o Fundo de Garantia por Tempo de Serviço, hoje regulamentado pela Lei n. 8.036, de 11 de maio de 1990, a qual dispõe sobre a indenização por dispensa sem justa causa, da seguinte forma: 
Art. 18. Ocorrendo rescisão do contrato de trabalho, por parte do empregador, ficará este obrigado a depositar na conta vinculada do trabalhador no FGTS os valores relativos aos depósitos referentes ao mês da rescisão e ao imediatamente anterior, que ainda não houver sido recolhido, sem prejuízo das cominações legais.

$\S 1^{\circ}$. Na hipótese de despedida pelo empregador sem justa causa, depositará este, na conta vinculada do trabalhador no FGTS, importância igual a quarenta por cento do montante de todos os depósitos realizados na conta vinculada durante a vigência do contrato de trabalho, atualizados monetariamente e acrescidos dos respectivos juros. (Grifo nosso).

$\mathrm{O} \S 1^{\circ}$, acima transcrito, é claro em aplicar referida indenização apenas aos casos de dispensa sem justa causa, não sendo aplicável, portanto, a lei do FGTS aos casos de despedida arbitrária, ficando esta regulada apenas pela expressa proibição do art. $7^{\circ}$, I, da Constituição Federal.

Não utilizou o legislador de termos distintos para tratar do mesmo conceito, até porque a lei não contém expressões inúteis; ou seja, não é sem razão que há na Constituição Federal menção à dispensa arbitrária e à dispensa sem justa causa. Faz-se ainda mais notória a diferença conceitual ao analisar o art. 165 da CLT (BRASIL, 1943), o qual considera arbitrária a dispensa que não seja fundada em aspecto disciplinar, técnico, econômico ou financeiro.

Corroborando esta tese, Jorge Luiz Souto Maior defende a existência de "quatro tipos de dispensa: a) a imotivada (que ora se equipara a dispensa arbitrária); b) a motivada (mas, sem justa causa); c) a com justa causa (art. 482, da CLT); e d) a discriminatória (prevista na Lei n. 9.029/95)", e explica cada uma delas, conforme abaixo:

A dispensa imotivada equipara-se à dispensa arbitrária e é proibida constitucionalmente.

A dispensa motivada (ou sem justa causa) dá ensejo ao recebimento pelo empregado de uma indenização equivalente a $40 \%$ sobre o FGTS.

A dispensa com justa causa, devidamente comprovada, nos termos do art. 482, da CLT, provoca a cessação do vínculo sem direito a indenização.

A dispensa discriminatória vem expressa quanto à definição e aos seus efeitos na Lei n. 9.029/95, dando ensejo à reintegração ou indenização compensatória. (SOUTO MAIOR, 2004). 
Em um raciocínio conceitual mais atento, difícil é imaginar que o empregador realmente dispensaria sem motivos seu empregado, pois se nenhum motivo tivesse para tanto, não o faria. E ainda, como diria Arion Sayão Romita:

Errônea é a expressão despedida imotivada. Não há despedida imotivada, despedida sem motivo: o empregador sempre sabe por que despede o empregado. (...) Portanto, qualquer ato voluntário obedece a motivos, é motivado, já o ato irracional é imotivado (ato do insano, do animal inferior). A despedida - ato voluntário do empregador, animal racional - é sempre motivada. Despedida imotivada é uma contradictio in terminis. (ROMITA, 1994, p. 4) (Grifo nosso).

Não se dando o direito de utilizar eufemismos criados com o fito de subverter as reais e obscuras intenções daqueles que insistem em crer na existência da despedida "imotivada", este estudo se limitará a denominá-la arbitrária.

Explicitada a inaplicabilidade da lei que regulamenta o FGTS à despedida arbitrária, e na remota e vetusta hipótese de reconhecimento da eficácia limitada e programática do dispositivo constitucional do art. $7^{\circ}$, I, resta uma evidente lacuna no ordenamento jurídico em relação ao tema.

Nos casos de lacuna, o Direito do Trabalho tem regra específica para nortear a atuação jurisdicional, consubstanciada no art. $8^{\circ}$ da Consolidação das Leis do Trabalho:

\begin{abstract}
Art. $8^{\circ}-$ As autoridades administrativas e a Justiça do Trabalho, na falta de disposições legais ou contratuais, decidirão, conforme o caso, pela jurisprudência, por analogia, por equidade e outros princípios e normas gerais de direito, principalmente do direito do trabalho, e, ainda, de acordo com os usos e costumes, o direito comparado, mas sempre de maneira que nenhum interesse de classe ou particular prevaleça sobre o interesse público.

Parágrafo único - $O$ direito comum será fonte subsidiária do direito do trabalho, naquilo em que não for incompatível com os princípios fundamentais deste. (Grifo nosso).
\end{abstract}

Socorrendo-se das regras de integração do Direto do Trabalho, previstas no art. $8^{\circ}$ da CLT, mostram-se aplicáveis os princípios gerais do direito do trabalho, bem como o direito comparado, para a solução do problema em tese.

Considerando que a Convenção n. 158 possui caráter inarredável de proteção aos direitos humanos, conforme já demonstrado, e que tal proteção é princípio prevalente no atual Estado Democrático de Direito, regendo a atuação brasileira em suas relações internacionais, por previsão expressa do art. $4^{\circ}$, inciso II, da Constituição Federal, certo é que pode ser considerada como tratado principiológico aplicável por força do art. $8^{\circ} \mathrm{da}$ 
CLT. Também se torna justificável sua aplicação por representar plenamente o princípio da permanência no emprego, uma das máximas realizadoras do princípio de proteção, tema este também já abordado no presente estudo.

Quanto ao direito comparado, no Fórum Internacional Sobre Direitos Sociais: Trabalho Decente e Desenvolvimento Sustentável, ocorrido nos dias 12 e 13 de agosto de 2010, o Sr. Arthur Henrique, então Presidente da CUT, trouxe o seguinte pronunciamento:

[...] além de França, Portugal, Espanha, Suécia, Austrália, Finlândia e os outros - mais de trinta países - que já ratificaram a Convenção, nunca é demais lembrar aquilo que foi falado aqui neste dia de hoje. Várias legislações constitucionais ou infraconstitucionais ou legislações trabalhistas existentes em vários países já adotam os temas da Convenção n. 158 da OIT, mesmo não ratificando a Convenção, como, por exemplo, acabou de ser falado aqui, Alemanha, Itália, Japão ou mesmo, mais recentemente, África do Sul. (HENRIQUE, 2010).

Portanto, seja pelo viés principiológico ou pela análise do direito comparado, a Convenção n. 158 da OIT é aplicável ao ordenamento jurídico brasileiro, ainda que se considerasse válida sua denúncia, ou mesmo que esta não tivesse sido ratificada pelo Brasil.

Não é sem precedentes jurisprudenciais que se chega a estas conclusões. No dissídio coletivo de natureza jurídica, instaurado contra a Empresa Brasileira de Aeronáutica - EMBRAER, sob o número 0030900-12.2009.5.15.0000, o qual tramitou perante o Tribunal Regional do Trabalho da $15^{\mathrm{a}}$ Região, decidiu-se pela aplicabilidade da Convenção n. 158 da OIT, por força do art. $8^{\circ}$ da CLT, para declarar a arbitrariedade da dispensa coletiva de 4,2 mil empregados.

Embora tal decisão tenha sido reformada no TST, pelo então Ministro Relator Maurício Godinho Delgado, há que observar que é de fato possível, pela análise jurídica ora apresentada, a aplicação da Convenção n. 158 da OIT ao atual ordenamento jurídico brasileiro, tanto que o Tribunal Regional do Trabalho da $15^{\mathrm{a}}$ Região o fez.

Conclusão

Por estar o tema da despedida arbitrária intimamente ligado à Convenção n. 158 da OIT, iniciou-se o estudo com a busca pelo entendimento da real aplicabilidade dos tratados internacionais sobre direitos humanos, ao sistema jurídico interno brasileiro. Para tanto, necessário compreender como e porque surgiram estes tratados, para aplicá-los conforme sua finalidade, compreendendo ainda como o Brasil reestruturou sua soberania 
e legitimou sua democracia pela ratificação de tratados internacionais sobre direitos humanos.

Antes da juridificação da linguagem dos direitos humanos, estes eram reconhecidos apenas como direitos fundamentais. Os direitos civis e políticos são os primeiros direitos a serem declarados fundamentais e inseridos em um tratado internacional, a Declaração dos Direitos do Homem e do Cidadão - 1789. O reconhecimento destes direitos buscou afastar o Estado absolutista monárquico das relações entre os particulares. Contudo, a classe operária surgida na Revolução Industrial estava destituída de qualquer proteção por parte do Estado em razão desta ideologia liberal, o que legitimou sua exploração, dando início à chamada questão social.

O caos social, que culminou na Primeira Guerra Mundial, foi sucedido de um tratado de paz, o Tratado de Versalhes firmado no ano de 1919, que criou a Organização Internacional do Trabalho - OIT, com finalidade de zelar pela justiça social e pelo respeito à dignidade humana, no que diz respeito ao trabalho do homem. Além deste tratado, outra marca importante do intervencionismo estatal foi o constitucionalismo social, que passou a levar direitos sociais às constituições de diversos países. Este contexto histórico firmou a segunda dimensão dos direitos fundamentais, dentre os quais o Direito do Trabalho tem especial ênfase neste estudo.

A falta de efetividade social dos direitos fundamentais até então reconhecidos contribuiu sobremaneira para a barbárie ocorrida na Segunda Guerra Mundial, nos anos de 1939 a 1945. Todo o sofrimento e a destruição ocorridos neste período internacionalizaram o sentimento de proteção à dignidade humana, trazendo em 1948 um importante tratado internacional, a Declaração Universal dos Direitos Humanos, que não apenas trouxe os direitos fundamentais de terceira dimensão, como juridificou aqueles já existentes e os reconheceu como patrimônio da humanidade, surgindo assim a expressão Direitos Humanos na acepção jurídica hoje utilizada.

Este tratado reconhece as dimensões de direitos humanos como postulados necessários para a construção da democracia, a qual é apontada neste documento como única solução legítima de organização do Estado, interferindo no âmbito jurídico e principalmente nos regimes políticos autoritários até então vigentes, para reconhecer que todo e qualquer direito fundamental depende de prestações positivas do Estado para se concretizar.

Esta interferência ocorreu no Brasil pela submissão ao Sistema Interamericano de Direitos Humanos, o qual exerceu fortes pressões políticas e financeiras aos países violadores desses direitos, para que ratificassem tratados internacionais sobre o tema, em troca da legitimação política no plano internacional.

Desta forma, verifica-se que o regime democrático brasileiro se deve intrinsecamente à ratificação de tratados internacionais sobre direitos humanos, os quais 
reestruturaram a soberania do país irradiando-a para órgãos internacionais de proteção destes direitos.

Dado à importância destes tratados internacionais, por força dos arts. 84, VIII e 49, I, da Constituição Federal de 1988, os poderes Executivo e Legislativo têm atuação necessária para sua conclusão. Assim, o chefe do Executivo negocia e assina o tratado e o encaminha para o referendo do poder Legislativo, e após aprovação legislativa o documento deve ser ratificado pelo Executivo para que possa tornar-se obrigatório no âmbito internacional e interno.

Enquanto os tratados internacionais tradicionais devem ser mediados pelo legislativo para que tenham eficácia interna, aqueles que versem sobre direitos humanos são plenamente acionáveis no exato momento de sua ratificação, por força do art. $5^{\circ}, \S \S$ $1^{\circ}$ e $2^{\circ}$, da Constituição Federal de 1988, valendo inclusive contra qualquer lei interna preexistente que seja com eles incompatível.

Sendo os tratados internacionais que versem sobre direitos humanos reconhecidos constitucionalmente pelo art. $5^{\circ}$, e considerando que referido artigo está inserido no título dos Direitos Fundamentais, conclui-se que estes instrumentos internacionais são, para o ordenamento jurídico brasileiro, cláusulas pétreas, conforme inciso IV, $\S 4^{\circ}$ do art. 60 da CF/88. Os demais tratados internacionais têm hierarquia infraconstitucional, mas supralegal, pela interpretação do art. 102, III, b, da CF/88, bem como do princípio da boa-fé esculpido no art. 27 da Convenção de Viena.

Embora a Emenda Constitucional n. 45/2004 tenha acrescentado o quórum de aprovação, previsto no $\S 3^{\circ}$ do art. $5^{\circ}$, aos tratados internacionais sobre direitos humanos, aqueles já ratificados não perderam seu caráter constitucional, haja vista a predominância material que condiciona a forma no plano jurídico-normativo.

A Constituição Federal de 1988 também trouxe importantes princípios que, pela hermenêutica constitucional contemporânea, foram alçados a normas plenamente acionáveis independente da interferência legislativa, quebrando a antiga ideia programática de seu conteúdo, sendo um de seus pilares o princípio da prevalência dos direitos humanos.

Explicitado o surgimento e entendida a finalidade dos tratados internacionais sobre direitos humanos, bem como a relação indissociável destes tratados com o sistema democrático e constitucional brasileiro, aprofunda-se o tema, que envolve a aplicabilidade da Convenção n. 158 da OIT, começando por demonstrar a relevância social internacional desta organização.

Criada pelo Tratado de Versalhes, a OIT surge com a missão de promover a paz social pela proteção do trabalho do homem, sendo posteriormente reconhecida como órgão permanente da ONU e recebendo, inclusive, o prêmio Nobel da Paz. Reconhecida como "consciência da humanidade", por promover efetiva proteção aos direitos humanos, a OIT também é reconhecida como grande realizadora do princípio protetor, que orienta 
o Direito do Trabalho. Princípio este que, para ser aplicável em sua plenitude, depende da continuidade da relação de trabalho, pois se permitida a ruptura dessa relação de forma arbitrária perde-se toda a proteção pretendida pelo instituto, podendo a despedida arbitrária ser utilizada, em muitos casos, como punição ou represália ao trabalhador.

Neste sentido a Convenção n. 158 estabelece que não haverá o término da relação de trabalho sem que haja causa fundada na capacidade ou comportamento do trabalhador ou baseada em necessidades de funcionamento da empresa, estabelecimento ou serviço. Qualquer outro motivo utilizado será considerado arbitrário. No Brasil, embora a Convenção n. 158 tenha sido assinada, ratificada, depositada e publicada, cumprindo todos os pré-requisitos formais para sua aplicabilidade nacional interna, no dia 20 de dezembro de 1996 foi publicada sua denúncia mediante o Decreto n. 2.100, com o intuito de abolir a vigência da convenção no ordenamento jurídico brasileiro.

Entende-se que a denúncia padece de invalidade formal por dois motivos. O primeiro envolve a ausência de consultas efetivas ao chamado "membro da OIT", que é composto não apenas pelo governo (Executivo e Legislativo), mas também pelos representantes dos empregados e dos empregadores, consulta esta traduzida pela vontade expressa da Convenção n. 144 da OIT ratificada pelo Brasil. O segundo se refere à intempestividade da denúncia, considerando o melhor entendimento sobre o início da contagem do decênio para tal ato.

Não bastassem as nulidades formais já explicitadas, a unilateralidade da denúncia pelo poder Executivo, sem a participação do poder Legislativo, fere o chamado "treaty-terminating power" estabelecido constitucionalmente. Ainda que houvesse referida participação, por tratar-se a Convenção n. 158 da OIT de tratado internacional sobre direitos humanos, há a discussão ou mesmo o impedimento de sua supressão por se tratar de direito indisponível.

E mesmo na mais liberal das hipóteses, aceitando a não aplicabilidade da convenção em comento, a boa-fé contratual e o conceito de abuso de direito põem entraves à despedida arbitrária e ao poder potestativo do empregador, os quais, nestes casos, dificultam o acesso à justiça e a efetiva prestação jurisdicional, podendo configurar, inclusive, ato ilícito indenizável.

Nesta mesma linha, torta, de aceitar a validade da denúncia da Convenção n. 158 da OIT, não se afasta a possibilidade de aplicação desta, como se observa na própria jurisprudência nacional, a qual argumenta que, tendo em vista a lei do FGTS ser aplicável apenas aos casos de despedida sem justa causa, ficaria a despedida arbitrária regulada unicamente pela proibição constitucional do art. $7^{\circ}$, I, da Constituição Federal, o qual, se interpretado como norma programática, estaria carente de regulamentação específica gerando clara lacuna legislativa. 
Assim, pelas normas de integração do Direito do Trabalho previstas no art. $8^{\circ}$ da CLT, a Convenção n. 158 seria plenamente aplicável como tratado principiológico ou mesmo pelo Direito comparado, haja vista sua ratificação e aplicabilidade em diversos países.

Ou seja, não importa qual o caminho jurídico que se busque na análise da vedação à despedida arbitrária, seja pela aplicação principiológica, convencional, constitucional, internacionalista, humanitária ou mesmo, na pior das hipóteses, civilista. Não é possível que se aceite a falácia despedida "imotivada" que há muito vem encobrindo as reais e obscuras intenções do capitalista mal-intencionado que insiste em precarizar o trabalho humano.

Não significa, contudo, que o empregador não tenha direito de dispensar seus empregados, mas apenas que deve justificar a despedida para que não continuem sendo legitimadas as nulidades e o desrespeito ao trabalho do homem, que há anos deixou de ser formalmente considerado objeto de mercado, mas ainda hoje busca afastar seus ranços de precarização.

Portanto, há que se retomar a finalidade clássica do Direito do Trabalho para que não estejamos em uma linha de retrocesso, da qual há muito se conhece os enormes danos trazidos à sociedade. Nas palavras de Fábio Konder Comparato:

$$
\begin{aligned}
& \text { ou a humanidade se deixa conduzir à dilaceração definitiva, } \\
& \text { na direta linha do apogeu capitalista, ou tomará afinal } \\
& \text { o rumo da justiça e da dignidade, seguindo o luminoso } \\
& \text { caminho traçado pela sabedoria clássica. Não há terceira } \\
& \text { via. (COMPARATO, 2010, p. 548). }
\end{aligned}
$$

Campinas, 9 de março de 2019.

\section{Referências}

ALVAREZ, Eduardo Oscar. Algunas precisiones en torno a la estabilidad propia y su dimensión axiológica. In: FERNÁNDEZ MADRID, Juan Carlos. Derecho laboral: doctrinas esenciales. Buenos Aires: La Ley Editora e Impresora, 1985.

BONAVIDES, Paulo. Curso de direito constitucional. 24. ed., atual. e ampl. São Paulo: Malheiros, 2009.

BRASIL. [Constituição (1988)]. Constituição da República Federativa do Brasil de 1988. Brasília, DF: Presidência da República, out. 1988.

BRASIL. Decreto Lei n. 5.452, de $1^{\circ}$ de maio de 1943. Aprova a Consolidação das Leis do Trabalho. Brasília, DF: Presidência da República, ago. 1943. 
BRASIL. Lei n. 10.406, de 10 de janeiro de 2002. Institui o código civil. Brasília, DF: Presidência da República, jan. 2002. Disponível em: http://www.planalto.gov.br/ccivil_03/leis/2002/L10406. htm. Acesso em: 6 nov. 2015.

BRASIL. Presidência de República Federativa do Brasil. Disponível em: http:www.presidencia. gov.br.

BRASIL. Supremo Tribunal Federal. Ação Direta de Inconstitucionalidade 1.625-3. Relator: Min. Joaquim Barbosa, 3 de junho de 2009. Disponível em: http:/www.stf.jus.br/arquivo/cms/ noticiaNoticiaStfArquivo/anexo/adi1625JB.pdf. Acesso em: 6 nov. 2015.

BRASIL. Tribunal Superior do Trabalho. Disponível em:http:www.tst.gov.br.

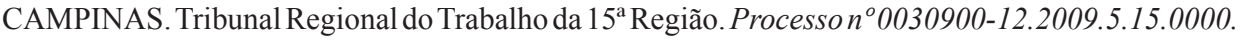
Relator: José Antonio Pancotti, 30 de março de 2009. Disponível em: http://consulta.trt15.jus.br/ consulta/owa/pDecisao.wAcordao?pTipoConsulta=PROCESSOCNJ\&n_idv=944968. Acesso em: 26 jan. 2016.

CANOTILHO, J. J. Gomes. Direito constitucional. 6. ed. rev. Coimbra: Livraria Almedina, 1993.

CARVALHO RAMOS, André de. Curso de direitos humanos. 2. ed. rev., atual. e ampl. São Paulo: Saraiva, 2015.

COMPARATO, Fábio Konder. A afirmação histórica dos direitos humanos. 7. ed., rev. e atual. São Paulo: Saraiva, 2010.

FERRAZ JÚNIOR, Tércio Sampaio. Introdução ao estudo do direito: técnica, decisão, dominação. 7. ed., rev. e ampl. São Paulo: Atlas, 2013.

GASPAR, Renata Alvares; MASTRODI, Josué. Sobre a construção da legitimidade interna e internacional do Sistema Interamericano dos Direitos Humanos: perspectiva política e jurídica no cenário brasileiro. Revista Fórum de Ciências Criminais, Belo Horizonte, v. 2, n. 3, p. 117-142, jan./jun. 2015.

HENRIQUE, Arthur. A importância da Convenção n. 158 da OIT para o trabalhador brasileiro. Revista do Tribunal Superior do Trabalho, São Paulo, SP, v. 76, n. 4, p. 69-76, out./dez. 2010. Disponível em: https://juslaboris.tst.jus.br/bitstream/handle/20.500.12178/18799/005_henrique. pdf? sequence=4\&isAllowed=y. Acesso em: 8 nov. 2015 .

MARMELSTEIN, George. Curso de direitos fundamentais. 5. ed. São Paulo: Atlas, 2014.

MIRANDA, Francisco Cavalcanti Pontes de. Comentários à Constituição de 1946. 3. ed. rev. e aumentada. Rio de Janeiro: Borsoi, 1960. v. 2.

NASCIMENTO, Amauri Mascaro. Curso de direito do trabalho: história e teoria geral do direito do trabalho: relações individuais e coletivas do direito do trabalho. 24. ed., rev., atual. e ampliada. São Paulo: Saraiva, 2009. 
NASCIMENTO, Cristina Reginato Hoffmann. A efetividade do direito do trabalho. 2011. Dissertação (Mestrado em Direito do Trabalho) - Faculdade de Direito da Universidade de São Paulo, São Paulo, 2011.

ORGANIZAÇÃO INTERNACIONAL DO TRABALHO. Constituição da OIT. 1946. Disponível em: https://www.ilo.org/wcmsp5/groups/public/---americas/---ro-lima/---ilo-brasilia/documents/ genericdocument/wcms_336957.pdf. Acesso em: 6 nov. 2015.

. Declaração da OIT sobre a justiça social para uma globalização eqüitativa, 2008. Disponível em: https:/www.ilo.org/wcmsp5/groups/public/---americas/---ro-lima/---ilo-brasilia/ documents/genericdocument/wcms_336918.pdf. Acesso em: 6 nov. 2015.

. Declaração da OIT sobre os principios e direitos fundamentais no trabalho. [2007]. Disponível em: https:/www.ilo.org/public/english/standards/declaration/declaration_portuguese. pdf. Acesso em: 6 nov. 2015.

. Disponível em: http:www.oitbrasil.org.br.

. História da OIT. Disponível em: https://www.ilo.org/brasilia/conheca-a-oit/ hist\%C3\%B3ria/lang--pt/index.htm. Acesso em: 6 nov. 2015.

PASUKANIS, Eugeny Bronislanovich. A teoria geral do direito e o marxismo. Rio de Janeiro: Renovar, 1989.

PIOVESAN, Flávia. Direitos humanos e o direito constitucional internacional. 11. ed. São Paulo: Saraiva, 2010.

PLÁ RODRIGUEZ, Américo. Princípios de direito do trabalho. 3. ed. atualizada. Tradução e Revisão Técnica de Wagner D. Giglio. São Paulo: LTr, 2000.

REVISTA DO TRIBUNAL SUPERIOR DO TRABALHO. Brasília, DF, v. 76, n. 4, out./dez. 2010. Disponível em: https://juslaboris.tst.jus.br/bitstream/handle/20.500.12178/18736/2010_rev_tst_ v076_n004.pdf?sequence=1\&isAllowed=y. Acesso em: 8 nov. 2015.

REZEK, José Francisco. Direito internacional público: curso elementar. 13. ed. rev., aumentada e atualizada. São Paulo: Saraiva, 2011.

ROMITA, Arion Sayão. Proteção contra a despedida arbitrária. Revista Trabalho \& Processo, São Paulo, n. 1, p. 3-35, jun. 1994.

SARLET, Ingo Wolfgang. A eficácia dos direitos fundamentais: uma teoria geral dos direitos fundamentais na perspectiva constitucional. 10. ed. rev., atual. e ampl. Porto Alegre: Livraria do Advogado, 2009.

SOUTO MAIOR, Jorge Luiz. Convenção n. 158 da OIT: dispositivo que veda a dispensa arbitrária é auto-aplicável. Revista Jus Navigandi, Teresina, ano 9, n. 475, out. 2004. Disponível em: https:// jus.com.br/artigos/5820/convencao-158-da-oit. 
SOUTO MAIOR, Jorge Luiz. A fúria. Revista LTr: legislação trabalhista, São Paulo, v. 66, n. 11, p. 1.287-1.309, nov. 2002.

SÜSSEKIND, Arnaldo Lopes. Convenções da OIT: constituição da OIT: convenções retificadas pelo Brasil... 2. ed. ampl. e atual. São Paulo: LTR, 1998.

. Parecer sobre consulta formulada pela Central Única dos Trabalhadores (CUT). Rio de Janiro, 1997. Disponível em: http:/www.conteudojuridico.com.br/consulta/Pe\%C3\%A7as\%20 Jur\%C3\%ADdicas/36507/parecer-por-arnaldo-sussekind-a-denuncia-da-convencao-n-158-porato-do-poder-executivo-sem-a-manifestacao-do-congresso-nacional-fere-o-sistema-constitucionalbrasileiro. Acesso em: 6 nov. 2015.

VIANA, Márcio Túlio. Proteção ao emprego e estabilidade sindical. Revista do Direito Trabalhista, Brasília, v. 7, n. 12, p. 18-20, dez. 2001. 